\title{
GOTHIC ELEMENTS IN THREE WORKS OF EARLY SPANISH ROMANTICISM
}

\section{ELEMENTOS GÓTICOS EN TRES OBRAS DEL PRE-ROMANTICISMO ESPAÑOL}

\author{
José Manuel Correoso Rodenas \\ Universidad Complutense de Madrid \\ jcorreos@ucm.es \\ Margarita Rigal Aragón \\ Universidad de Castilla-La Mancha \\ margarita.rigal@uclm.es
}

\begin{abstract}
:
The awakening of Gothic in literature in 1764 marked a milestone in the development of the Western literary canon. The inclusion of the supernatural and the horrific provoked the end of the reign of Enlightenment and opened the door for Romanticism. In Spain it took a while longer for the new literary trend to flourish. However, a group of writers who had published during the last decades of the eighteenth century started to include gothic elements in their works, creating Enlightenment-Gothic hybrids. Some of these authors were Gaspar Melchor de Jovellanos, José Cadalso and Juan Meléndez Valdés. Their El delincuente honrado, Noches lúgubres, and "A Jovino, el melancólico," respectively prove that gothic and sublime aesthetics also affected Spanish belles lettres.
\end{abstract}

Key words: Spanish Gothic; $18^{\text {th }}$ century; Jovellanos; José Cadalso; Meléndez Valdés

\section{Resumen:}

El surgimiento de la literatura gótica en 1764 supuso un hito en el desarrollo del canon literario occidental. La inclusión de lo sobrenatural y lo terrorífico provocó el final del reinado de la Ilustración y allanó el camino al Romanticismo. En España, su florecimiento se haría esperar algo más. Sin embargo, un grupo de escritores que habían venido publicando desde las últimas décadas del siglo XVIII comenzaron a incluir elementos góticos en sus obras, creando híbridos entre el espíritu ilustrado y la literatura gótica. Algunos de esos autores fueron Gaspar Melchor de Jovellanos, José Cadalso y Juan Meléndez Valdés. Sus El delincuente honrado, Noches lúgubres y "A Jovino, el melancólico", respectivamente, prueban que las estéticas gótica y sublime ya se habían integrado en las belles lettres españolas.

Palabras clave: Gótico español; siglo XVIII; Jovellanos; José Cadalso; Meléndez Valdés 
Artículo. José Manuel Correoso Rodenas, Margarita Rigal Aragón. “Gothic Elements in Three Works of Early Spanish Romanticism"

... Crudelis ubique

Luctus, ubique pavor, et plurima noctis imago. ${ }^{1}$

Early Gothic literature, as well known, developed in Europe during the second half of the eighteenth century. Traditionally, it has been considered that this genre was neglected genre within Spanish letters. However, we claim that a handful of Spanish authors did, in fact, recreate many of the motifs used by their European peers, with the additament of Spanish conventions and idiosyncratic characteristics. To prove our hypothesis we will revisit a selection of texts by three of the main representatives of Spanish transition from Enlightenment to Romanticim: Gaspar Melchor de Jovellanos's El delincuente honrado, José Cadalso's Noches lúgubres and Juan Meléndez Valdés's “A Jovino, el melancólico,", who developed their own, personal gothic through the inclusion of sublime aesthetics.

Conventional scholarship on the matter has only approached the subject tangentially when studying authors or movements related to the topic (see Sebold, for instance). In recent decades, scholars such as Luis Alberto de Cuenca, David Roas, Miriam López Santos, and Xavier Aldana Reyes have started to consider Spanish Gothic by itself. This step forward constitutes a new milestone in the development of a complete comprehension of what gothic literature really meant in Spain, leaving pre-conception or obsolete views behind, as this essay proves.

Since its very beginning, Gothic literature was the source of a large amount of criticism. Many of these analytical texts were created by the same authors who produced gothic novels, but others were composed by "critics" or intellectuals who witnessed the rise of this new literary genre. Within this second group, it is possible to find names such as Walter Scott or the Marquis de Sade. The work of the former is important nowadays to our understanding of the genre, especially the works of Ann Radcliffe (1764-1823), one of the leaders of the gothic movement in England.

In Spain, as it had happened with Gothic works, the opinions of intellectuals took longer to arrive; it was not until the first decades of the nineteenth century that these started

\footnotetext{
${ }^{1}$ Cadalso took this quotation, which serves to open Noches Lúgubres, from Virgil's Aeneid: “All things were full of horror and affright,/And dreadful ev'n the silence of the night" (lines 368-369, book two of The Aeneid, translated by John Dryden into English). See https://www.gutenberg.org/files/228/228-h/228-h.htm.
} 
to be expressed. Some important names are cited among those first figures who understood that the works of José Cadalso, Eugenio de Ochoa, Telesforo de Trueba y Cossío, among others, did not belong to any national tradition, but were more easily related to the new novel created by Horace Walpole. According to Miriam López Santos (2010), these authors are of such a importance as "Clavijo, Cadalso, los Iriarte, Jovellanos, Moratín y muchos otros" (20), who considered witches "[...] reliquias paganas transmitidas a la literatura" (López Santos 20). Xavier Aldana Reyes has also recently discussed on the nature and evolution of Spanish Gothic, linking Catholicism and the birth of the genre in Spain: "[...] some of the greatest Spanish Gothic writers happened to by staunchly Catholic and that Catholicism privileges a form of engagement with the supernatural that eschews the real [...]" (3). In this way, Aldana Reyes has attempted to differentiate the Spanish Gothic from the more widely accepted literary trend of Realism. ${ }^{2}$ However, there were other authors who considered Gothic and Romanticism, and fantastic literature as something lacking importance if compared to Neoclassicism and more realistic trends in letters. For example, David Roas (2006) comments the judgments of José de Urcullu: “[...] la naciente literatura fantástica [es un] género menor, fácil de componer, que los escritores escriben por dinero y el público popular lee con fruición" (Roas 30). This popular perspective was one of the main obstacles that gothic literature had to face in Spain, along with the inquisitorial and governmental control and the lack of a tradition.

Among those who studied Gothic and its related themes, Benito Jerónimo Feijoo deserves to be highlighted. This intellectual friar of the Enlightenment is mostly known for his attacks on superstition and ignorance as part of the main problems within Spanish history and, more concretely, within the linkage between secular and religious power in Spain. Nevertheless, his articles also dealt with aesthetic ideas, and it is there where his relationship with gothic literature arises. For example, his essay "El no sé qué," formerly part of one of his greatest works -Teatro critico universal-, opens with a paragraph that can perfectly be understood as an apology for the supernatural:

\footnotetext{
${ }^{2}$ According to him, then, any work produced in Spain and suspicious of being somehow related to the Gothic, was immediately condemned: "Under this new light, and for the sake of argument, the Gothic in Spain could be read as that which has deliberately doomed itself to the pursuit of transgression and of that which is not religiously or culturally sanctioned" (Aldana Reyes 2).
} 
En muchas producciones, no sólo de la naturaleza, mas aun del arte, encuentran los hombres, fuera de aquellas perfecciones sujetas a su comprensión, otro género de primor misterioso, que cuanto lisonjea el gusto, atormenta el entendimiento; que palpa el sentido, y no puede descifrar la razón; y así, al querer explicarle, no encontrando voces ni conceptos que satisfagan la idea, tal cosa tiene un no sé qué, que agrada, que enamora, que hechiza, y no hay que pedirles revelación más clara de este natural misterio (Feijoo, Teatro 225; Feijoo's italics).

That "no sé qué" will later be turned into the ghosts, specters, and monsters that populate the labyrinthine pages of gothic novels, adding a quasi-eerie view to Feijoo's understanding of the supernatural (which, obviously, began in his relationship with religion). Art and Literature were not the only topics in which Feijoo's genius worked. As already mentioned, his main field, as a son of his century, was to achieve the improvement of Spanish people, mainly through culture and education. One of the tasks that Feijoo and his peers intended to accomplish was the elimination of superstition and popular beliefs that were, firstly against Catholicism and, secondly, against reason. Paradoxically, when trying to achieve this noble goal, Feijoo had to give many explanations of these beliefs, such as witches, vampires, ghosts, etc., addressing issues such as their existence, their nature, or how these beings could be understood from a Christian perspective. Both in his Teatro crítico and in his Cartas eruditas y curiosas it is possible to find examples of topics related to Gothic or which were to be used by Gothic authors in many different ways; this is the reason why Luis Alberto de Cuenca states:

[...] una serie de títulos de Feijoo [...] contribuirían al refuerzo de esta tendencia supersticiosa "Astrología judiciaria y almanaques", "Duendes y espíritus familiares", "Vara adivinatoria y Zahoríes", "Milagros supuestos", "Piedra filosofal", "Cuevas de Salamanca y Toledo y mágica de España", (Teatro crítico) y "Entierros prematuros", "De la transportación mágica del obispo de Jaén" y "El judío errante" (Cartas eruditas) (Cuenca, 39).

Miriam López Santos also points Feijoo as one of the main contributors to the spreading of these superstitions within Spain:

Que existen brujas, confiesa, lo sabemos por las Sagradas Escrituras y las autoridades de la Iglesia, pero ni mucho menos tantas como los ignorantes creen y las confesiones de estas, en muchos casos, no pasaban 
de considerarse meras fantasías del miedo o de mentes enloquecidas por la tortura [...] (López Santos 21).

A remarkable example of this is letter 20 of Cartas eruditas y curiosas. This epistle was given the suggestive title of "Reflexiones críticas sobre las dos disertaciones que, en orden a apariciones de espíritus y los llamados vampiros, dio a luz poco ha el célebre benedictino famoso expositor de la Biblia don Agustín Calmet." Indeed, in 1746, the French monk Augustin Calmet, published his Traité sur les apparitions des esprits et sur les vampires ou les revenans de Hongrie, de Moravie, \&c. In this treaty, the monk exposes several dubious cases, possible causes of how a person would become a vampire and how to "deal" with them. Feijoo, in his letter, far from offering only a review of Calmet's text, tries to give an explanation to the supernatural events that, even in the eighteenth century, were believed as true. To do this, Feijoo resorts to religion and theology, in which he finds a way to clarify these events:

Esto no sólo es un sentimiento universal de los católicos, mas claramente lo insinúa el Concilio Tridentino en la sesión 25, en el decreto del Purgatorio, por aquellas palabras: Purgatorium ese, animasque ibi detentas etc., en las cuales se manifiesta que hay un lugar destinado para la purificación de las almas, el cual se llama purgatorio, y en él están detenidas (detentas) padeciendo para este efecto. Mas si creemos la relación de Pedro Engelbert, no hay tal lugar común donde las almas están detenidas; antes acá andan vagueando en peregrinaciones para expiar las culpas en los sitios mismos donde las cometieron (Feijoo, Cartas 273; Feijoo's emphasis).

Regarding this trend of faith, the possible existence of ghosts and/or vampires is not totally excluded by Feijoo and his contemporaries, as Alonso Palomar asserts: "Existe un desequilibrio entre lo que su práctica mente dieciochesca quería desarraigar y el contenido que sus escritos ofrecen, ya que su teoría sobre la magia tiene un fuerte arraigo teológico y una importante base histórica" (Alonso Palomar 130). Knowing this and having also in mind that Feijoo was one the most renowned and recognized intellectuals in Spain during Charles III and Charles IV reigns, it is not extremely difficult to understand how the first wave of gothic (or proto-gothic) literature was developed in this country, one of the most reticent to adopt foreign examples in the following decades. Religious and cultural issues, and the permanence of the Inquisition were some of the reasons for this reticence. An 
Artículo. José Manuel Correoso Rodenas, Margarita Rigal Aragón. “Gothic Elements in Three Works of Early Spanish Romanticism"

explanation for this can be the noticeable anticlericalism of novels (especially English and French), although the authors included in this essay do not contradict the postulates of religion. They are only served with gothic elements to build their plots and characters, leaving the religious debate to the forthcoming generation.

Benito Jerónimo Feijoo was, however, not the only voice that dealt with gothicrelated concepts. In the second half of the century, a Catalonian officer and philosopher, who later would participate in the Cortes of Cádiz, Antonio Capmany Surís y de Montpaláu, wrote an essay entitled Filosofia de la elocuencia. Even if the first objective of this text was to paraphrase Immanuel Kant's Beobachtungen über das Gefühl des Schönen und Erhabenen [Observations on the Feeling of the Beautiful and Sublime], it contained the most important Spanish approximation to the term sublime, at least until the advent of Spanish Romanticism (in the fourth decade of the nineteenth century):

[...] la esencia de lo sublime [...] no consiste en decir cosas pequeñas con un estilo remontado y florido, sino cosas grandes con una expresión simple y natural. La grandeza debe estar en el asunto, y por esta causa un pensamiento sublime dispensa el trabajo de buscar la expresión relevante [...]. Lo sublime en todas las cosas siempre envuelve un sentimiento profundo de admiración o respeto, nacido de la terribilidad de los objetos [...] en la naturaleza los objetos que excitan sensaciones más fuertes son siempre la profundidad de los cielos, la inmensidad de los mares, las erupciones de los volcanes, los estremecimientos de los terremotos, etc., por razón de las grandes fuerzas que en ella suponen, y por la comparación que involuntariamente hacemos de estas mismas fuerzas con nuestra debilidad al tiempo de observarlas. En la contemplación de unas cosas de por sí formidables, ¿qué hombre no se sentirá poseído del más tímido y profundo respeto? (Capmany Surís y de Montpaláu 141-143).

The reader can notice the similarities between this description and the later one provided by Ann Radcliffe in her essay "On the Supernatural in Poetry," in which she defines both the terms of terror and horror: "Terror expands the soul and awakens the faculties to a high degree of life. Horror contracts, freezes and nearly annihilates them" (Radcliffe 1826: 149). Russell P. Sebold points out a direct influence of Capmany's treaty on one of the studied pieces in this essay: "[...] existe un mayor paralelo de tonalidad entre la definición que da este filósofo y el estilo de A Jovino: el melancólico" (Sebold, "Neoclasicismo" 194). This means that the European ideas of the sublime, through the lens of a Spanish interpretations, 
had already permeated the intellectual circles of Spain. Thus, the relationship of Spanish Gothic with its European counterpart is stronger that thought at first.

To find the third clear relation of Spanish eighteenth-century Gothic and European or mainstream Gothic, it is necessary to look directly at Strawberry Hill, Horace Walpole's manor where The Castle of Otranto was composed. His friend and companion James MacPherson, mainly famous for his labor as antiquarian and poet, published in 1763, the works of Ossian. Later on, this would be discovered to be one of the greatest literary hoaxes ever performed. Neither Ossian nor his epic poems existed, but they were a creation of MacPherson himself. The plot of these texts dealt with a mythological Irish and Scottish Celtic past, in which heroes such as Fionn mac Cumhaill or Oisín would have resisted foreign invasions and "contamination" as early as the third century AD. As Walpole recognized, these fake poems were one of the sources he used to compose his gothic novel. They were also influential to Spanish writers at the end of the eighteenth century, ${ }^{3}$ as Russell P. Sebold states: "La primera versión castellana de Ossián fue estampada en 1788, aunque se habían publicado traducciones a otras lenguas románicas a partir de 1763. Los poemas de Meléndez Valdés [...] fueron, en efecto, influidos por Ossián" (Sebold, "Neoclasicismo" 200). ${ }^{4}$ Some of the Ossianic characteristics that were taken by Spanish authors were, according to Sebold (2015), “[...] la presencia y el papel de la sensibilidad lacrimosa, el lenguaje de la pasión, el exotismo medievalista, los sepulcros, las ruinas, la modalidad 'gótica' y los acentos ossiánicos en las obras del primer Romanticismo español” (Sebold, "Introducción" 196). As it is easily noticeable, most of these elements would later be used by Gothic authors, both in Spain and in the rest of Europe.

As previously seen, early Spanish Romanticism is, in many cases, narrowly related to Gothic and gothic-related terms. Then, it will not be surprising to discover that texts by main representatives of the Enlightenment, such as Meléndez Valdés, Cadalso, or Jovellanos also present characteristics developed by gothic authors. This will be examined later on, but it is worthy to point out that, more concretely, Cadalso used Edward Young's Night Thoughts as a source of inspiration, linking both Spanish and English trends under

\footnotetext{
${ }^{3}$ One of the most outstanding examples of this Ossianic influence is the long poem Oda a Malvina, by Juan Ángel Caamaño, Spanish author and translator.

${ }^{4}$ For more information about the influence of Ossian in Spanish letters, see the book by Isidoro Montiel included in the references.
} 
Artículo. José Manuel Correoso Rodenas, Margarita Rigal Aragón. “Gothic Elements in Three Works of Early Spanish Romanticism"

the dome of Gothic and macabre. ${ }^{5}$ The next sections will explore how all the previously mentioned characteristics become part of a corpus of works produced during the last stages of the Spanish Enlightenment and the first of its Romanticism.

\section{El delincuente honrado (1773)}

The first work to be analyzed is the drama entitled El delincuente honrado, written by the thinker and statesman Gaspar Melchor de Jovellanos. Jovellanos's relationship with the European Gothic can be, primarily, stated in terms of Art, for Architecture was one of the many fields the Asturian studied. For instance, in 1805, he would write an essay under the title of Sobre la arquitectura inglesa y la llamada gótica. Here, as Alejandro Sanz de la Torre has pointed out, Jovellanos: “[...] mantuvo la originalidad de la arquitectura gótica, al no ser simple copia de la naturaleza y poseer contenidos de índole espiritual, primando lo imaginativo sobre lo real" (Sanz de la Torre 436). Later on, Sanz de la Torre would also claim the even higher importance of this essay, since it was, along with his Memoria del castillo de Bellver, descripción histórico-artística (1805), “[...] una evolución en la obra de Jovellanos que estuvo marcada por el tránsito de una ideología ilustrada y racionalista a otra prerromántica, influenciada por autores como Rousseau, Burke y Shaftesbury” (Sanz de la Torre 440). The fact that Jovellanos can be related to Burke makes it possible to think that this Spanish author could have had some notions of the concept of the sublime that was being developed in the rest of the continent at that moment.

El delincuente honrado shares some of the main characteristics of the European Gothic, such as the presence of the gothic villain, the imprisonment of the innocent, or the perverse father acting against his own offspring. To intensify the poignancy of the play, Jovellanos designed a plotline in which it was finally discovered that Don Justo was Torcuato's unknown father, who had left his mother without knowing she was carrying a baby.

Before proceeding with the analysis of the two main gothic elements present in the play, it is necessary to point some other minor elements that also appear in El delincuente honrado. The first of them, especially remarkable due to its important relation to the

\footnotetext{
${ }^{5}$ F. O. Lovejoy, in his essay "The Meaning of Romanticism for the Historian of Ideas," explores these connections.
} 
Gothic, is an explicit mention to the Goths. Near the end of the play, Don Justo, after having condemned Torcuato, reflects with Don Simón (Laura's father) about the nature of the Law in Spain: "En cada obra la acción es complicada por un nuevo edicto excesivamente severo con los duelos; cada protagonista [...] es el primero en violar el edicto, y en cada caso el rey quiere aplicar la nueva ley al primer reo en forma dura para fijar un sano precedente legal y penal" (Sebold, "Introducción" 59). In this context, Don Justo's paragraph acquires new importance, showing how the Goths' rule was fairer than the contemporary, as British legislators and writers had been claiming all along the century (such as Alexander Pope or William Godwin):

JUSTO: Cuando haya mejores ideas acerca del honor, convendrá acaso asegurarlas por ese medio; pero entre tanto las penas fuertes serán injustas y no producirán efecto alguno. Nuestra antigua legislación era en este punto menos bárbara. El genio caballeresco de los antiguos españoles hacía plausibles los duelos, y entonces la legislación los autorizaba; pero hoy pensamos, poco más o menos, como los godos, $\mathrm{y}$, sin embargo, castigamos los duelos con penas capitales (Jovellanos 155).

The second of these minor gothic elements is the mention both Torcuato and Anselmo make of distant and exotic locations. When Torcuato considers the possibility of fleeing to save his life, Anselmo is willing to follow his friend and master wherever he goes, and Siberia arises as, apparently, the first plausible option: "ANSELMO: [...] ¿Quieres que te siga? ¿Que vayamos juntos a los desiertos de Siberia? [...]” (Jovellanos 114). Later on (Act II, Scene V), just before Anselmo is unjustly sent to prison, Torcuato decides to leave, and so informs his wife: "TORCUATO: [...] Voy a huir de ti para siempre, y a esconder mi vida detestable en los horrible climas donde no llega la luz del sol, y donde reinan siempre el horro y la oscuridad" (Jovellanos 126). The mention of both horror and darkness link his imagined fate to most of the locations of the Gothic (abbeys, castles, forests...) and even to Hell and to the future destiny he will have to confront in prison, where he almost dies.

Probably, the most obvious gothic element is the inclusion of the figure of the gothic villain. From The Castle of Otranto (and its Manfred) on, many (in-) famous gothic villains have populated the pages of the movement, having some of them become cultural pieces: Caliph Vathek (from Vathek), Montoni (from The Mysteries of Udolpho), Ambrosio 
Artículo. José Manuel Correoso Rodenas, Margarita Rigal Aragón. “Gothic Elements in Three Works of Early Spanish Romanticism"

(from The Monk), Schedoni (from The Italian), John Melmoth (from Melmoth the Wanderer), etc. From a first reading of the plot, it can be deduced that Torcuato is the tobe-feared character of the story. However, it is soon discovered that the true villain is not him, not even one of the characters playing a part in the play. The villain, the man full of vices and perversions is the deceased marquis of Montilla, the man Torcuato killed. When both Torcuato and Anselmo are discussing whether or not it is convenient for the first to confess his crime before he is prosecuted (Act I, Scene III), Anselmo tries to alleviate his friend's guilt appealing to the just act he committed:

ANSELMO: [...] Es verdad que has muerto al marqués de Montilla; pero lo hiciste insultado, provocado y precisado a defender tu honor. Él era un temerario, un hombre sin seso. Entregado a todos los vicios, y siempre enredado con tahúres y mujercillas, después de haber disipado el caudal de su esposa, pretendió asaltar el de su suegro y hacerte cómplice en este delito (Jovellanos 113).

Within this paragraph, some of the main characteristics of the marquis are portrayed (treacherous, vicious, gambler, etc.). Most of them are shared by some of the previously mentioned villains, especially the Caliph Vathek and the monk Ambrosio. Both the marquis and Ambrosio try to involve someone else in their perverse doings (Antonia and Torcuato, respectively). Later on, when Torcuato is being interrogated by Don Justo, once again he bases his defense on the fact that the marquis deserved his fate: "TORCUATO: [...] Mi ofensor, señor, era uno de aquellos hombres temerarios a quienes su alto nacimiento y una perversa educación inspiran un orgullo intolerable" (Jovellanos 149-150). This second quotation offers an important detail for analysis: the reference to the education of the marquis. Education, along with villainy, has been a very recurrent argument within the Gothic. This refers (mainly) not to and established or formal education, but to the assimilation of customs, traditions, and doings that have been transferred from generation to generation, contributing to the creation of the corrupt families or institutions appearing in the gothic novel (being, perhaps, the Inquisition one of the most relevant examples).

Narrowly linked to the gothic villain, violence impregnates the whole play. Personal and collective violence flourish in the pages of gothic novels, performed both by human or supernatural characters. When reading El delincuente honrado, one can notice the apparent lack of violence (especially if compared with classical gothic works) in a play dealing with 
a homicide. Indeed, the first act of violence of the drama takes place before its plot begins, and it is the actual murder of the marquis of Montilla, as Torcuato's own confession assest: "TORCUATO: Ya sabes que fui autor de la muerte del marqués de Montilla, y que este funesto secreto, que hoy llena mi vida de amargura, se conserva entre los dos" (Jovellanos 111). This quasi-Shakespearean event turns out to be the trigger element of the whole story, condemning Torcuato, but also allowing him to find his long-time disappeared father. The murder of the marquis leads to the second main source of violence within the story, as well. This is the imprisonment of Anselmo, an innocent, who offers himself to save his friend. Once Anselmo has been put into prison, and prior to Torcuato's final confession, there is a scene (Act II, Scene XIV) in which the murderer, alone, reflects about his friend being imprisoned. His main concern is not the possible sentence he can face (most likely execution since the victim was an aristocrat) but the possibility of torture:

TORCUATO: [...] ¡Anselmo tiene contra sí tantas sospechas...! Si se obstina en callar, sufrirá todo el rigor de la ley... Y tal vez la tortura... (Horrorizado.) ¡La tortura...! ¡Oh nombre odioso! ¡Nombre funesto...! ¿Es posible que en un siglo en que se respeta la humanidad y en que la filosofía derrama su luz por todas partes, se escuchen aún entre nosotros los gritos de la inocencia oprimida...? (Jovellanos 132).

Jovellanos, by the inclusion of a character suffering such a circumstance, makes himself a first-rate follower of the gothic novel, where passages, dungeons, and chambers of torture were common. This section also opens a new possible way within the gothic trend: that not only ecclesiastical tribunals were sources of horror, but civil ones, too, based on an unequal organization of society.

Also, one of the first topics developed by the Gothic novel is the leitmotiv of the unfeeling parents, specially exploited at the beginning of the genre by Horace Walpole. His two main gothic creations (The Castle of Otranto and The Mysterious Mother) present parents whose aim is to damage their children in one way or another. Jovellanos also decided to use this resource when composing his El delincuente honrado. However, it must be noted that, unlike the previous examples, Don Justo is an unconscious father who does not know the identity of his punished son. It has been previously mentioned that Anselmo is unjustly charged for the murder of the marquis of Montilla. Soon after, Torcuato, following his conscience, goes to the court and confesses his guilt, consequently freeing his friend. At 
Artículo. José Manuel Correoso Rodenas, Margarita Rigal Aragón. “Gothic Elements in Three Works of Early Spanish Romanticism"

this point, neither Don Justo not Torcuato are conscious of the relation they have. Once the sentence is dictated and irrevocably signed by the judge, the truth arises. When Don Justo discovers he has condemned his own son, he doubts between accomplishing his duty as a public servant and listening to his feelings. Anselmo, once again, will become the only relief this character has.

JUSTO: Sí, amigo mío; esta bárbara sentencia ha sido dictada por su mismo padre.

ANSELMO: (Asombrado) ¿Vos padre suyo? ¡Oh, Dios!

JUSTO: (Transportado de pena) No, yo no soy su padre; soy un monstruo, que le ha dado la vida para arrebatársela después... (Jovellanos 158-159).

Nevertheless, prior to this scene, Torcuato had already starred one in which he had been portrayed as a classical Romantic hero, ${ }^{6}$ when he points the circumstance of having been raised without a father at the core of all his troubles:

TORCUATO: (Abatido) El cielo me ha condenado a vivir en la adversidad. ¡Qué desdichado nací! Incierto de los autores de mi vida, he andado siempre sin patria ni hogar propio, y cuando acababa de labrarme una fortuna, que me hacía cumplidamente dichoso, quiere mi mala estrella... (Jovellanos 115).

Even if Jovellanos cannot be considered as a gothic author, this tragedy unequivocally shows certain knowledge of the new movement and style that was beginning to be developed in Europe (mainly in England and Germany, cultures the Spanish writer knew well). The inclusion of the mentioned gothic elements can be interpreted both as an assimilation of those new trends and as the opening of a new way in Spanish letters which would be developed by later authors, such as José Cadalso.

\footnotetext{
${ }^{6}$ As Sebold notes: "En este fragmento, Torcuato parece haber intuido ya el siguiente del héroe romántico [...]. Pudiéramos mencionar otros numerosos ejemplos de héroes románticos de orígenes misteriosos, desconocidos, o aun sospechosos, pero que en el fondo son virtuosos hijos de la naturaleza o buenos salvajes, en obras románticas decimonónicas de diversos géneros -teatro, novela, poesía narrativa- [...]" (Sebold, "Introducción” 115 -footnote 31-).
} 


\section{Noches lúgubres (1789-1790)}

Noches lúgubres was written by José Cadalso, a colonel of the Royal Spanish Army, who was one of the most outstanding authors of Spanish Enlightenment. Most probably Cadalso began producing his first "Noche" by 1774 . According to Glendenning, the author could have seen a manuscript dating back to 1775 in the British Museum ${ }^{7}$. Helman (1959) established that the very first edition was the one published in Correo de Madrid between the months of December 1789-February 1790. Later on the text suffered numerous changes and apocryphal additions. The fact that the last night (night three) finishes in medias res has also induced to the thought of it being unfinished. However, Sebold gives an explanation that seems plausible:

Es muy feliz la conclusión de las Noches lúgubres en lo que atañe a la relación entre realidad y procedimiento mimético. La noche III $-\mathrm{y}$ así la obra - termina in medias res. Lorenzo y Tediato están a punto de coger el pico y el azadón para ir una vez más al sepulcro de la que fue Hermosa doncella de cabello de oro [...]. El dolorido amante le dice al guardián de los difuntos: "Andemos, amigo, andemos", y no hay ya nada más. Final abierto (Sebold, "Introducción" 106).

Traditionally (Glendinning, 1962; Arce, 1996), Noches lúgubres has been considered an autobiographical text based on the suicidal feelings of Cadalso after the death of María Ignacia Sánchez. This legend of a "Cadalso desenterrador" (as a desecrator of tombs) was mainly due to the addition of an anonymous letter "Carta de un amigo a otro, en la que manifiesta el resumen de los amores de Cadalso con la Ibáñez y da la idea de la obra que hace por este efecto," which was introduced in the 1822 edition of Noches lúgubres. ${ }^{8}$ Nevertheless, in his letter LXVII (Cartas marruecas), Cadalso stated that Noches was finished and that he had written it on behalf of the death of a male friend:

\footnotetext{
${ }^{7}$ For further information on this issue, see Felipe B. Pedraza Jiménez and Milagros Rodríguez Cáceres, Manual de literatura española V. Siglo XVIII.

8 “A pesar del éxito de esta segunda versión, no satisfacía la exaltación de cierto sector de la juventud romántica. Precisamente durante el Trienio Constitucional -época políticamente exaltada- se publica una tercera versión de Noches lúgubres a la que se le añade una 'Noche cuarta'. Sale en Madrid en 1822 sin nombre de impresor" (Dowling 110).
} 
Si el cielo de Madrid no fuese tan claro y hermoso y se convirtiese en triste, opaco y caliginoso como el de Londres [...] me atrevería yo a publicar las Noches lúgubres, que he compuesto a la muerte de un amigo mío, por el estilo de las que escribió el doctor Young. La impresión sería en papel negro con letras amarillas, y el epígrafe [...]

... Crudelis ubique

Luctus, ubique pavor, et plurima noctis imago (Cadalso 301).

Apart from the discussion about the open or closed ending of the text, its literary genre opens another controversial topic. Noches lúgubres is a lyrical poem in prose, although it can also be considered that Cadalso might have been thinking of composing a play, as Quiziano and Sebold have argued:

Como es bien sabido, el texto se inscribe claramente en el modelo de la poesía sepulcral en boga en aquellos decenios, aunque la presencia determinante de los diálogos y soliloquios aproximan a las Noches mas a una obra para ser representada o recitada en los escenarios (Quinziano 404).

Teatro, diálogo didáctico,
lírica y respecto de esta
última aún hay otro
elemento nuevo: la prosa.
En las Noches lúgubres
tenemos un poema lírico en
prosa, prosa dialogada. Es el
primer poema en prosa de la
literatura española [...]
(Sebold, "Introducción" 98).

The work develops through dialogues between the major protagonist, the young Tediato (tedium) that has just lost his beloved Filis, and his helper, Lorenzo, in charge of burying the new deceased. Each of the three night opens with a long soliloquy by Tediato and continues with a dialogue between the two men, being the comments of Lorenzo shorter and sharper than the protagonist's. Tediato's lover has passed away. Tediato asks Lorenzo to help him to open the temple. Lorenzo and the reader discover at the same time that Tediato wants to exhume the buried corpse of his treasured Filis. His final purpose is to take her body to his own house, to commit suicide and to put the house in flames so that their ashes are together for eternity. Lorenzo agrees to do this if he is conveniently rewarded. Daylight arrives and they decide to postpone the disinterment of the corpse for the following night. At the beginning of the second night, the protagonist hears screams coming from a group of people, then a mortally injured man approaches Tediato; seconds 
later the forces of the law arrive to find Tediato covered in blood. Tediato is consequently imprisoned and he hopes for his death. When the prison-keeper arrives with two other men, Tediato thinks he has been condemned, without a trial, to death penalty. However, he is released because the real killers have been found. It is still dark outside and Tediato decides to head towards the temple and see if Lorenzo is still waiting for him. Lorenzo is not there, but his little son (called also Lorenzo) is. Lorenzo's father has just died, and so has his wife. Unable to attend to his appointment with Tediato, he sends his own son to explain his absence. The child and the protagonist go now to Lorenzo's house where they agree to meet again by the temple, the following night. The third night, a very short one, indeed, opens with a long soliloquy in which Tediato summarizes the events of the two previous nights and complains about fate (his own, Lorenzo's, and the world's); the two men meet for a third time, and they start their steps, carrying peaks and hoses, towards the temple.

Due to the nocturnal, sepulchral and deeply lyrical tone of the text, many have regarded this as the very first romantic Spanish work. For instance, Menéndez Pelayo defined Cadalso as the first Spanish romantic writer "realizando [...] el ideal apasionado y tumultuoso de los Byron y los Esproncedas" (Menéndez Pelayo 296) ${ }^{9}$; Ramón Gómez de la Serna and Helman further developed this same belief: ${ }^{10}$ "el título, el escenario, el tema, los personajes y su manera de hablar, su forma de relato corto y melodramático, todo es romántico" (Helman, "The First" 42). Lately, the debate has intensified. Sebold justifies the romanticism of the work but explains the presence of realistic elements which were typical of the eighteenth century philosophy: "No es, en el fondo, nada sorprendente que la primera obra plenamente romántica de Europa ... encierre, por decirlo así, una segunda obra subtextual de prisma realista [...] pues el realismo y el romanticismo tienen raíces comunes en la filosofía sensista dieciochesca [...]" (Sebold, "Introducción" 108). However, Arce argues that Cadalso follows exactly the European models of his time: "[...] empapado en la ideología de la Ilustración, que cree en el hombre, en la razón humana [...]” (Arce 1992: 47). This said, Arce pinpoints that "Cadalso es, en una palabra, el introductor en la literatura española de lo que se ha llamado el Prerromanticismo" (Arce 47). Afterwards, Arce also claims: "Cadalso es, con todo, el creador, en nuestra literatura, del género

\footnotetext{
${ }^{9}$ See Marcelino Menéndez y Pelayo, Historia de las ideas estéticas v. 3.

${ }^{10}$ Regarding this topic and the opinions of Gómez de la Serna, see, for instance, his chapter, "El primer romántico de España, Cadalso el desenterrador," in Biografias completas. Mi tía Carolina Coronado.
} 
Artículo. José Manuel Correoso Rodenas, Margarita Rigal Aragón. “Gothic Elements in Three Works of Early Spanish Romanticism"

sepulcral, dentro de una concepción pesimista del hombre cuya voluntad -más ostentada que realizada - de destrucción y autodestrucción es manifiesta" (Arce 49). Quinziano (2010) and Martínez Mata (2000) ${ }^{11}$ agree with Arce that it is a mistake to talk about "Romanticism" fifty years before the movement had started: "Cadalso es fiel a una moda literaria, que no es la de cincuenta años más tarde, sino la de su tiempo" (Arce 48). An argument that matches our own premises; Cadalso's works are the result of the Age of Reason, but Noches Lúbugres is the result of its own time, an age in which classic Gothic and sublime aesthetic were at their peak.

Taking into account these antecedents, and bearing in mind other characteristics of the work, we are now going to explore the gothic elements in Noches lúgubres. First of all, Cadalso had spent an important part of his childhood and teen years in Europe. French and English languages were as familiar to him as Spanish. It comes with no surprise, then, that Cadalso stated that he was following the style of Dr. Young when writing his Noches. Many critics have studied the plausibility of this and concluded that if there was any "inspiration," it was just in the use of the term "nights," and the choice of the name "Lorenzo" (Glendinning, 1962; Arce, 1996; Martínez Mata, 2000; Sebold, 2015, etc.). These same critics have also pinpointed other more feasible sources such as La difunta pleiteada by Lope de Vega, Meditations and Contemplations by James Hervey, or The Citizen of the World by Oliver Goldsmith.

Secondly, being Cadalso a man of the world, with a vast knowledge, able to read in English, would it not be ilogical to assume that he was familiar with Burke's writings on the sublime, with the new gothic trend as introduced by Walpole. As seen, critics talk of a romantic Cadalso (but with some doses of realism), of a preromantic Cadalso, of the creator of a sepulchral genre, of a vision of the Cosmos that was afterwards baptized as "mal du siècle," "Welteschmerz," or "fastidio universal," depending on the country. In Sebold's words: "Este sentirse sin compañía ni divina ni humana, con el alma tan vacía como el mundo de fuera, [...] lleva al perpetuo llanto, interior cuando no exterior, y posiblemente al suicidio" (Sebold, "Introducción” 93). The intense presence of macabre elements supports

\footnotetext{
11 Martínez Mata asserts: "Tediato hace un ejercicio de racionalismo continuo ante lo misterioso o sobrenatural” (Martínez Mata 46).
} 
this postulate, too, as Martínez Mata states: "los detalles macabros de la exhumación, con los gusanos de la tumba recorriendo el pie de Tediato" (Martínez Mata 41).

Being this so, it is not surprising that many gothic elements were present in Cadalso's Noches. Let's go through some of them, starting with the first characteristic that is typical of this movement, one we find when reading Noches: "iQué noche! La oscuridad, el silencio pavoroso, interrumpidos por los lamentos que se oyen en la vecina cárcel [...]" (Cadalso 367). Indeed, it is during the night when the action of these three episodes takes place; and during those nights darkness intensifies: "La noche es tan oscura y espantosa" (Cadalso 369), being also "terrible," as terrible will prove the whereabouts of Tediato and Lorenzo. Apart from being dark, the weather adds more gothic terror to the situation: "El cielo también se conjura contra mi quietud, si alguna me quedara. El nublado crece. La luz de esos relámpagos..., iqué horrorosa! Ya truena. Cada trueno es mayor que el que le antecede, y parece producir otro más cruel" (Cadalso 367). Not only the menacing weather but also nature itself as a frightening component appears here; a good example is the moment in which Tediato wonders: "Lorenzo no viene. ¿Vendrá, acaso? ¡Cobarde! ¿Le espantará este aparato que Naturaleza le ofrece?” (Cadalso 368). However, although night time can bring dreads, it is also the preferred moment of the day for the souls and the deeds of gothic character:

¡Con qué dolor han visto mis ojos la luz del astro, a quien llaman benigno los que tienen el pecho menos oprimido que yo! (Cadalso 387).
¡Noche!, dilata tu duración; importa poco que te esperen con impaciencia el caminante para continuar su viaje y el labrador para seguir su tarea. Domina, noche, domina, y más y más sobre un mundo que por sus delitos se ha hecho indigno del sol. Quede aquel astro alumbrando a hombres mejores que los de estos climas.

Mientras más dure tu oscuridad, más tiempo tendré de cumplir la promesa que hice al cadáver encima de su tumba, en medio de otros sepulcros, al pie de los altares y bajo la bóveda sagrada del templo (Cadalso 400). 
The two main characters, Tediato and Lorenzo, are of different nature. Tediato represents tedium, as his name indicates. He is the example of the "fastidio universal," he is seeking death, thinking of suicide but also open to welcoming any other way to perish. His melancholy is similar to the gothic characters of Manfred (The Castle of Otranto), or Don Raymond (The Monk), for instance. Through Tediato's opening lines the reader gets acquainted with these moods: "La oscuridad, el silencio [...] completan la tristeza de mi corazón. [...]; todo se inunda en llanto..., todo tiembla. [...]” (Cadalso 367). As said, he wants to finish with his life: “¡Ay, si este fuese el último día de mi vida, cuán grato sería para mí!" (Casalso 367-368), even savouring the arrival of his last days on earth: "Lo que me es gustosa es la muerte... Dádmela cuanto antes, si os merezco alguna misericordia. Si no sois tan benigno, dejadme vivir; ése será mi mayor tormento" (Cadalso 392). It is only at the end of night one that the reader (and his companion, Lorenzo) knows the reason why this is so: "Pronto volveré a tu tumba, te llevaré a mi casa, descansarás en un lecho junto al mío; morirá mi cuerpo junto a ti [...] y tú y yo nos volveremos ceniza en medio de la casa" (Cadalso 386). On the other hand, Lorenzo is a very earth grounded character. He has even more problems than the protagonist, however, he pledges to reality. For instance, when Tediato describes a "monster" (Cadalso 377) he saw some days before at the temple, Lorenzo rationalizes the event by adding that the same evening his dog had gone missing (Cadalso 378). Here, it is possible to identify another distinctive feature of gothic texts: something that was presumed as belonging to the world of phantoms turns out to have a perfectly normal explanation. Also, when Lorenzo is trying to discover why Tediato wants to open a sepulchre, his first thought is that he has to be searching for some treasure, or money (Cadalso 374); once Tediato explains it is not money but the corpse of a very dear person, Lorenzo assumes it has to be his son, his mother, this father, etc. (Cadalso 386). Lorenzo also complains once and again about the reality of what they find in the tomb: “¡Qué olor! ¡Qué peste sale de la tumba! No puedo más. [...] La abertura que forma ya da lugar para que salgan esos gusanos que se ven con la luz de mi farol" (Cadalso 383).

As we have mentioned, Lorenzo has just lost his father, his wife, and two of his children are very ill. The feelings he shows towards his family are different from Tediato's. As an archetypal gothic character, Tediato thinks negatively of family relationships: "No te 
canses Lorenzo; nada significan esas voces que oyes de padre, madre, hermano, hijo y otras tales; y si significan el carácter que vemos en los que así se llaman, no quiero ser ni tener hijo, hermano, padre, madres, ni me quiero a mi mismo [...]" (Cadalso 381). The same kind of feelings can be appreciated, as shown above, in Jovellanos's El delincuente honrado.

Another important gothic component -murder- is included at the beginning of the second night, while Tediato waits for Lorenzo by the temple. However, in this case, the act of murder itself or who the murderer is are of no importance but an excuse to introduce the space of the prison, one of the most prototypical in gothic texts: "Sepulcro de vivos, morada de horror, triste descanso en el camino del suplicio, [...], abre tus puertas; recibe a este infeliz" (Cadalso 394). Apart from assimilating the prison to the grave, Cadalso seems to be trying to allude to the Inquisition without actually mentioning it; nevertheless, the methods described are those known to have been employed by this institution.

Cadalso chose, then, to set the action of Noches in the typical space and atmosphere of gothic texts. Besides, he decided to follow a tone frequently found in the writings of this trend: a satirical tone in which the grotesque is emphasised. For instance, at the end of the second night, in a very ironical way, Tediato recommends Lorenzo to bury himself and the rest of his family:

Te compadezco tanto como a mí mismo, Lorenzo, pues la suerte te ha dado tanta miseria y te la multiplica en tus deplorables hijos... Eres sepulturero... Haz un hoyo muy grande, entiérralos todos ellos vivos, $\mathrm{y}$ sepúltate con ellos. Sobre tu losa me mataré y moriré diciendo: Aquí yacen unos niños tan felices ahora como eran infelices poco ha, y dos hombres, los más míseros del mundo (Cadalso 403-404).

As shown, the whole text is full of allusions to necrophilia. What is somewhat unexpected is that when opening the grave of his beloved one, the melancholic Tediato complains of the macabre reality he and Lorenzo are confronted with:

¡Ay, qué veo! [...] ¡Cuánta miseria me anuncian! En éstos, ¡ay!, ¡en éstos se ha convertido tu carne! ¡De tus hermosos ojos se han engendrado estos vivientes asquerosos! ¡Tu pelo, que en lo fuerte de mi pasión llamé mil veces no sólo más rubio, sino más precioso que el oro, ha producido esta podre! ¡Tus blancas manos, tus labios amorosos se han vuelto materia y corrupción! ¡En qué estado estarán las tristes reliquias de tu cadáver! ¡A 
Artículo. José Manuel Correoso Rodenas, Margarita Rigal Aragón. “Gothic Elements in Three Works of Early Spanish Romanticism"

qué sentido no ofenderá la misma que fue el hechizo de todos ellos! (Cadalso 383-384).

In this way, it can be appreciated that Tediato is not a romantic hero, but a man of reason who cannot but see reality, even if he complains and does not want to accept it. At the end of the text Tediato insists on the ideas present in the soul of a man afflicted with the "mal du siècle," ideas present in the philosophy and the literature of any historical moment.

\section{“A Jovino, el melancólico" (1794)}

Finally, the last text we are going to consider is Juan Meléndez Valdés's elegiac poem “A Jovino, el melancólico,"12 dedicated to Jovellanos. Valdés was a member of the Spanish Royal Academy, considered the most recognized poet of the Spanish eighteenth century, being his works included halfway between the Neoclassicism and the Romanticism, as Antonio Astorgano Abajo (2004) asserts:

Todos los críticos actuales reconocen que Meléndez fue el máximo representante de la poesía de su tiempo. A partir de ahí cada uno se fija en aspectos concretos. Salinas (1925) destaca la elevación del tono poético. Real Ramos (1991) resalta que Meléndez fue precursor del empleo del romance histórico-legendario, que revitalizó el empleo del heptasílabo asonantado y el endecasílabo suelto. Admitió como objeto lírico los temas científicos y sociales. Abrió al Romanticismo el camino del sentimentalismo y de la confesionalidad (Astorgano Abajo 74).

His poetry is mainly known for the recovery of classical models, such as Greek anacreontics. ${ }^{13}$ However, part of his composition is far from this model, including elements that will later be explored by Romantic authors and which can be easily related to Gothic. "A Jovino, el melancólico" is one of those examples.

As is has already been seen for Cadalso's Noches lúgubres, the first discussion worthy to be brought to mind is that of the genre, or, more specifically, of the movement in which the poem should be included. Despite being a poem following a traditional classic

\footnotetext{
12 “[...] [el] el más billante y conmovedor poema nocturno del siglo XVIII español," according to Irene Gómez Castellano (Gómez Castellano 260).

13 This type of verse ("de arte menor") is usually utilized by authors for bucolic and/or Hedonistic representations in which wine and the pleasures of life are often included. The name derives from the Greek poet Anacreon ( $c a .582-485 \mathrm{BC})$.
} 
pattern, the figures Valdés used to compose the rhetoric of the verses make it to stand closer to Romanticism. As seen in the previous examples, the testimony of Russell P. Sebold has also been given for this text. Irene Gómez Castellano, pledging to Sebold's statement, continues to provide evidence on why "A Jovino, el melancólico," can be considered a Romantic example:

[...] la desesperación de los versos [...] y, sobre todo, la expresión "fastidio universal", son la prueba de cómo el romanticismo surge sin necesidad de viajar desde Inglaterra o Alemania, de la propia "evolución" interna del sentimiento ilustrado y de la estética neoclásica que suele acompañarle, y que deviene romántico en algunos poemas [...] (Gómez Castellano 259).

As can be easily deduced from the title of the poem, its main topic is melancholy. This means that the text lacks a plot and a characterization as found in the previous examples included in this study. So, the gothic elements susceptible to appear in "A Jovino, el melancólico" will refer to the author's use of words and of rhetorical figures. It is especially relevant how Meléndez Valdés includes words associated to the night ${ }^{14}$ and to horror. Terms and expressions such as "lóbrega noche," "horror," "muerte," "sepulcro," or "letal veneno" appear up to thirteen times in a poem 166 verses long.

Probably, the two fragments in which the gothic-like atmosphere is present are those of the first and fifth stanzas (vv. 1-9 and 69-85). The elegy opens with the description of the sunset in which not only the sun is hiding, but also the happiness of the poet's soul, so deadly thoughts arise with darkness:

Cuando la sombra fúnebre y el luto de la lóbrega noche el mundo envuelven en silencio y horror, cuando en tranquilo

reposo los mortales, las delicias gustan de un blando saludable sueño, tu amigo solo, en lágrimas bañado, vela, Jovino, y al dudoso brillo de una cansada luz en tristes ayes

\footnotetext{
${ }^{14}$ For a wider understanding of Valdés's used of night and day metaphors, see Gómez Castellanos's previously mentioned article.
} 
Artículo. José Manuel Correoso Rodenas, Margarita Rigal Aragón. “Gothic Elements in Three Works of Early Spanish Romanticism"

contigo alivia su dolor profundo (Meléndez Valdés 865 , vv. 1-9). ${ }^{15}$

The first two verses announce the tone and the main characteristics of the poem: death and darkness will arise as the main thoughts of the author and of the poetical voice within the elegy, assimilating the author's soul with that of Jovino, to expand their friendship to the darkest corners of reality. The impossibility of happiness causes in the poet a denial of the possibility of ever being happy, claiming pain as his only solace.

From these verses on, the poem advances following an in crescendo model up to the fifth stanza. During the previous ones, images as those of the poet being poisoned by the thought of Jovino, the appreciation of Jovellanos's virtues or the total despair of the poetical voice ("Yo, empero, huyendo de él [the Sun], sin cesar llamo/ la negra noche, y a sus brillos cierro/ mis lagrimosos fatigados ojos", Meléndez Valdés 866, vv. 58-60) arise. The final verses of the fourth stanza function as an introduction to the fifth; in them, the poet claims to be somehow a lover of the night:

La noche melancólica al fin llega, tanto anhelada: a lloro más ardiente, a más gemidos su quietud me irrita.

Busco angustiado el sueño: de mí huye despavorido; y en vigilia odiosa me ve desfallecer un nuevo día, por el clamando detestar la noche (Meléndez Valdés 866-67, vv. 62-68).

In relation to this, another of Irene Gómez Castellano's acknowledgements is worth to the brought here:

[...] la luz no desaparece por completo de su elegía. Como si quisiera buscar sentido en tanta oscuridad, el poema se esfuerza por recuperar la luz de la razón, y así aparece la aurora iluminando el poema temporalmente. Pero el sujeto poético huye de esa luz, que le causa más dolor, y se queja de su incapacidad de conciliar el sueño, de su "vigilia

\footnotetext{
${ }^{15}$ It is interesting to see the contrast with the second stanza, in which day and light are the key elements of the

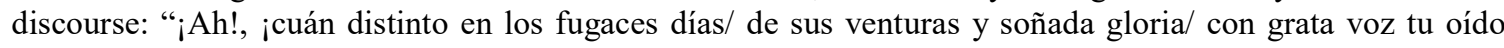
regalaba!,/ cuando ufano y alegre, seducido/ de crédula esperanza al fausto soplo,/ sus ansias, sus delicias, sus deseos/ depositaba en tu amistad paciente,/ burlando sus avisos saludables./ Huyeron prestos como frágil sombra,/ huyeron estos días; y al abismo/ de la desdicha el mísero ha bajado" (Meléndez Valdés 865, vv. 10-20).
} 
dolorosa". Ni el día ni la noche consuelan a Batilo de su tedio, de su "fastidio universal" (Gómez Castellano 260).

As previously mentioned, all this crescendo reaches its climax at the fifth stanza of the elegy. There, the poetical voice directly talks to Death, imploring its arrival as a mean to scape his present miserable condition:

La muerte implore, y a mi voz la muerte cierra dura el oído; la paz llamo, la suspirada paz que ponga al menos alguna leve tregua a las fatigas en que el llagado corazón guerrea; con fervorosa voz en ruego humilde alzo al cielo las manos: sordo se hace el cielo a mi clamor; la paz que busco es guerra y turbación al pecho mío (Meléndez Valdés 867, vv. 77-85).

On the one hand, some of the images employed by Meléndez Valdés in this stanza are closely related to Father Feijoo's theories, as we have explained in the previous pages. Benito Jerónimo Feijoo recognized the communication with the supernatural as something possible, and Valdés's poetical alter ego does the same: he deals with Death with the true desire of meeting him. On the other hand, the behavior of the poet is also similar to that to some prototypical gothic characters (i.e., Walpole's Isabella and Matilda, Lewis's Antonia, etc.) who seek Death as the only refuge against the tyrannical destiny the narration is hiding for them. However, the poem does not end here. It goes on for four more stanzas in which this climate does not change and the poet alternates the dialogues with Jovino and with Death/the universe. His sad fate also continues: [...] Todo, todo/ se trocó a un infeliz (Meléndez Valdés 868, vv. 120-121). Nevertheless, the last two stanzas use an aesthetic resource that links the style of "A Jovino, el melancólico" to the previously analyzed Noches lúgubres, since, as above stated, Tediato is afflicted with the "mal du siècle." Juan Meléndez Valdés is not unfamiliar with this trend and expressed it at the end of his elegy. The last two stanzas begin with a parallel structure used to inform his interlocutor of how extreme his pain is: 
¡Ay!, ¡si me vieses elevado y triste, inundando mis lágrimas el suelo, en él los ojos, como fría estatua inmóvil y en mis penas embargado, de abandono y dolor imagen muda! (Meléndez Valdés 868, vv. 131-135).
¡Ay!, ¡si pudieses ver... el devaneo de mi ciega razón, tantos combates, tanto caer y levantarme tanto, temer, dudar, y de mi vil flaqueza indignarme afrentado, en vivas llamas ardiendo el corazón al tiempo mismo! (Meléndez Valdés 868, vv. 140-145).

These verses show the impossibility of relief for the poet, and also how all his attempts to reach happiness have been futile. Now, he is defeated and destroyed, and Jovino is the only desirable witness of his fall in disgrace.

\section{Conclusion}

The analysis of these three works by Jovellanos, Cadalso, and Meléndez Valdés has proved that Gothic aesthetic and taste did not only develop in the rest of the European continent, but they also found their counterpart in Spain, both in the theoretical and in the literary modes. The writings of Benito Jerónimo Feijoo, Antonio Capmany Surís y de Montpaláu, and others, can be contemplated in parallel with those of the European theorists of the genre, such as the Marquis de Sade or Edmund Burke. The examples provided by Gaspar Melchor de Jovellanos, José Cadalso, and Juan Meléndez Valdés show the Gothic was also included in the Spanish battle against Enlightenment, as it was happening in Britain, France, or Germany, for instance. Their gothic villains, and/ or murderers, their treacherous and vicious characters, the value of education, the sublimity of nature, the stressed necrophilia, nocturnal and dark scenarios, etc., are as vivid and intense as those of any other author related to the gothic genre. Their works (and the subsequent examples that the next generation would produce) are good statements against the usual and naive affirmation of Spanish literature as being only realist. The memory of the Goths, the macabre and the night of the soul lie far from this, making these authors spearheads of the movement within Spain. The elements depicted and analyzed in this study will later be used by a generation of romantic authors, in whose works death, darkness, and impossibility will rate high (José de Espronceda, José Zorrilla, the Duke of Rivas, Gustavo Adolfo Bécquer, 
etc.). However, their works would not have been so witty and dark without the intercourse with these other authors, as Keats, Byron, Coleridge, or Scott's would not have been possible without Walpole, Lewis, or Radcliffe's.

\section{REFERENCES}

Aldana Reyes, Xavier. Spanish Gothic. National Identity, Collaboration and Cultural Adaptation, Palgrave Macmillan, 2017.

Alonso Palomar, Pilar. Brujas, demonios y fantasmas en la literatura fantástica hispánica. Universitat de Lleida, 1999.

Arce, Joaquín. "Introducción." Cartas marruecas. Noches lúgubres, by José Cadalso. Cátedra, 1992, pp. 11-59.

Astorgano Abajo, Antonio. "Introducción.” Obras completas, by Juan Meléndez Valdés. Cátedra, 2004, pp. 19-90.

Cadalso, José. Cartas marruecas. Noches lúgubres. Cátedra, 2015.

Capmany Surís y de Montpaláu, Antonio. Filosofía de la elocuencia. Juan Francisco Piferrer, 1826.

Cuenca, Luis Alberto de. "La literatura fantástica española del siglo XVIII." Anthropos: Boletín de información y documentación, núm. 154-155, 1994, pp. 38-44.

Dowling, John. "Las Noches lúgubres de Cadalso y la juventud romántica del Ochocientos." Coloquio internacional sobre José Cadalso, Bolonia, octubre de 1982. Piovan Editore, 1985, pp. 105-124.

Feijoo, Benito Jerónimo. Cartas eruditas y curiosas. Crítica, 2009.

---. Teatro crítico universal. Cátedra, 2012.

Glendinning, Nigel. Vida y obra de Cadalso. Gredos, 1962.

Gómez Castellano, Irene. "De lo diurno a lo nocturno en la poesía de Meléndez Valdés." eHumanista, núm. 22, 2012, pp. 252-271.

Gómez de la Serna, Ramón. Biografías completas. Mi tía Carolina Coronado. Aguilar, 1959.

Helman, Edith F. "Introducción.” Noches lúgubres, by José Cadalso. Taurus, 1968, pp. 9-65.

---. “The First Printing of Cadalso's Noches lúgubres.” Hispanic Review, vol. XVIII, 1959, pp. 126-134.

Jovellanos, Gaspar Melchor de. El delincuente honrado. Cátedra, 2013.

López Santos, Miriam. La novela gótica en España (1788-1833). Editorial Academia del Hispanismo, 2010.

Lovejoy, F. O. "The Meaning of Romanticism for the Historian of Ideas.” J.H.I., vol. II, no. 3, 1941.

Martínez Mata, Emilio. "Prólogo.” Cartas Marruecas. Noches lúgubres, by José Cadalso. Crítica, 1996 [2000] pp. xxxi-lxxxix.

Meléndez Valdés, Juan. Obras completas. Cátedra, 2004.

Menéndez y Pelayo, Marcelino. Historias de las ideas estéticas. Vol. 3. Aldus, 1940.

Montiel, Isidoro. Ossián en España. Planeta, 1974. 
Pedraza Jiménez, Felipe B. and Milagros Rodríguez Cáceres. Manual de literatura española V. Siglo XVIII. Cénlit Ediciones, 1981.

Quinziano, Franco. 'Las 'Noches lúgubres' cadalsianas: humanitarismo, sensismo y nueva sensibilidad en la literatura dieciochesca." RILCE. Revista de Filología Hispánica, vol. 26, no. 2, 2010, pp. 402-430.

Radcliffe, Ann. "On the Supernatural in Poetry." The New Monthly Magazine and Literary Journal, 1826, pp. 145-152.

Roas, David. De la maravilla al horror. Los inicios de lo fantástico en la cultura española (1750-1860). Mirabel Editorial, 2006.

Sanz de la Torre, Alejandro. "Jovellanos y la reivindicación de la arquitectura gótica de Palma." Espacio, tiempo y forma, vol. VIII, no. 6, 1993, pp. 433-470.

Sebold, Russell P. "Introducción.” Cartas marruecas. Noches lúgubres, by José Cadalso. Cátedra, 2015, pp. 13-125.

---. "Neoclasicismo y Romanticismo dieciochescos." Historia de la literatura española. Volumen I, edited by Víctor García de la Concha, Espasa Calpe, 1995, pp. 137-208.

Walpole, Horace. The Castle of Otranto. Oxford University Press, 1996.

http://jardindelosclasicos.blogspot.com.es/2016/12/el-dificil-camino-de-la-razonlas_10.html?utm_source $=$ feedburner\&utm_medium $=$ twitter\&utm_campaign $=$ Feed: + ElJardinDeLos $\overline{C l a s i c o s}+(\mathrm{El}+\mathrm{Jard} \% \mathrm{C} 3 \% \overline{\mathrm{ADn}}+\mathrm{de}+\mathrm{los}+\mathrm{Cl} \% \mathrm{C} 3 \% \overline{\mathrm{A}} 1$ sicos $)$ 